\title{
Correction to: Dual-energy CT collagen density mapping of wrist ligaments reveals tissue remodeling in CPPD patients: first results from a clinical cohort
}

\author{
Katharina Ziegeler ${ }^{1} \cdot$ Sophia-Theresa Richter ${ }^{1} \cdot$ Sandra Hermann $^{2} \cdot$ Kay Geert A. Hermann $^{1} \cdot$ Bernd Hamm $^{1}$. \\ Torsten Diekhoff ${ }^{1}$
}

Published online: 13 July 2021

(c) The Author(s) 2021

\section{Correction to: Skeletal Radiology (2021) 50:417-423 https://doi.org/10.1007/s00256-020-03580-z}

The article "Dual-energy CT collagen density mapping of wrist ligaments reveals tissue remodeling in CPPD patients: first results from a clinical cohort", written by Ziegeler, K., Richter, ST., Hermann, S., Hermann, KA., Hamm, B., \& Diekhoff, T. , was originally published Online First without Open Access. After publication in volume 50, issue 2, page 417-423 the author decided to opt for Open Choice and to make the article an Open Access publication. Therefore, the copyright of the article has been changed to () The Author(s) 2020 and the article is forthwith distributed under the terms of the Creative Commons Attribution 4.0 International License, which permits use, sharing, adaptation, distribution and reproduction in any medium or format, as long as you give appropriate credit to the original author(s) and the source, provide a link to the Creative Commons licence, and indicate if changes were made. The images or other third party material in this article are included in the article's Creative Commons licence, unless indicated otherwise in a credit line to the material. If material is not included in the article's Creative Commons licence and your intended use is not permitted by statutory regulation or exceeds the permitted use, you will need to obtain permission directly from the copyright holder. To view a copy of this licence, visit http://creativecommons. org/licenses/by/4.0. Open access funding enabled and organized by Projekt DEAL.

Open Access This article is licensed under a Creative Commons Attribution 4.0 International License, which permits use, sharing, adaptation, distribution and reproduction in any medium or format, as long as you give appropriate credit to the original author(s) and the source, provide a link to the Creative Commons licence, and indicate if changes were made. The images or other third party material in this article are included in the article's Creative Commons licence, unless indicated otherwise in a credit line to the material. If material is not included in the article's Creative Commons licence and your intended use is not permitted by statutory regulation or exceeds the permitted use, you will need to obtain permission directly from the copyright holder. To view a copy of this licence, visit http://creativecommons.org/licenses/by/4.0/.

Publisher's note Springer Nature remains neutral with regard to jurisdictional claims in published maps and institutional affiliations.

The original article can be found online at https://doi.org/10.1007/ s00256-020-03580-z

Katharina Ziegeler

katharina.ziegeler@charite.de

1 Department of Radiology, Charité-Universitätsmedizin, Charitéplatz 1, 10117 Berlin, Germany

2 Department of Rheumatology and Clinical Immunology, Charité-Universitätsmedizin, Charitéplatz 1, 10117 Berlin, Germany 